\title{
HLA Analysis of CD15+ Granulocytes of Leukemic Patients and Assessment of its Implication in Leukemia Immunotherapy
}

\author{
Durjoy Majumder ${ }^{1,2}$, Subrata Banerjee ${ }^{1}$, Debasis Bandyopadhyay ${ }^{3}$ and Sarmila \\ Chandra ${ }^{4}$ \\ ${ }^{1}$ Biophysics \& Structural Genomics Division, Saha Institute of Nuclear Physics, 1/AF Bidhannagar, Kolkata \\ ${ }^{2}$ Department of Physiology, West Bengal State University, Berunanpukuria, Malikapur, Barasat, 24 Pgs.
} (N), Kolkata

${ }^{3}$ Hematology Unit, Department of Pathology, Ramakrishna Mission Seva Pratishthan, Kolkata

${ }^{4}$ Department of Hemato-Oncology, Kothari Medical Center, Kolkata

Correspondence should be addressed to: Durjoy Majumder; durjoy@rocketmail.com

Received date: 20 March 2014; Accepted date: 9 June 2014; Published date: 19 September 2014

Academic Editor: Pavel Jindrà

Copyright @ 2014. Durjoy Majumder, Subrata Banerjee, Debasis Bandyopadhyay and Sarmila Chandra. Distributed under Creative Commons CC-BY 3.0

\begin{abstract}
It is of common knowledge that most leukemic patients succumb to infectious complications beside dysfunction in proliferation/differentiation of hematopoietic cells. Recently, it has been shown by several groups that there is a locus specific HLA class I downregulation in the leukemic cells. However, the HLA status of the phenotypically/morphologically normal granulocytes which can cope up with the infectious complications are not known. Therefore it may be worthwhile to study the HLA status in these cell types. We, therefore, investigated the status of HLA-ABC and HLA-DR in the CD15+ granulocytes and observed a higher expression of HLA-DR in several leukemic samples in comparison to normal volunteers (NV). Our data also suggest that only $\mathrm{CD} 15^{+}$granulocytes of myeloid leukemia, a clonal stem cell disorder, have a tendency of decreased HLA class Ia antigen expression. Moreover CD15 ${ }^{+}$granulocytes of NV showed an enhanced HLA-DR expression in presence of leukemic cells. Interestingly, CD15 ${ }^{+}$ granulocytes collected from normal volunteers were observed to have phagocytic oxidative burst activity towards HLA class Ia downregulated primary leukemic cells. We therefore suggest that neutrophil transplantation may be used for the treatment of leukemia.
\end{abstract}

Keywords: HLA, polymorphonuclear neutrophil, CIITA, innate immunity

Cite this Article as: Durjoy Majumder, Subrata Banerjee, Debasis Bandyopadhyay and Sarmila Chandra (2014), "HLA Analysis of CD15+ Granulocytes of Leukemic Patients and Assessment of its Implication in Leukemia Immunotherapy ", Research in Immunology: An International Journal, Vol. 2014 (2014), Article ID 982078, DOI: 10.5171/2014. 982078 


\section{Introduction}

Polymorphonuclear neutrophils (PMNs) constitute about $75 \%$ of the white blood cells of normal individuals' peripheral blood and are the major component (>90\%) of the granulocytes. They take part in the acute inflammatory response and are the primary immune effector cells against extracellular pathogens. They can be activated by macrophage- and endothelial- derived cytokines. Neutrophils express Fc receptors for IgG and complement receptors and thus bind and phagocytose opsonized antigens, providing an important link between innate and humoral immunity (Pure, 2000). PMN has got special importance in hematological malignancies as the majority of patients of all types show infectious complications associated with neutropenia in AML (Estey et al, 2000), ALL (Dubansky et al, 1989; Benz et al, 2000; Hoelzer, 2000), CML (Crammer et al, 1977), and MDS (Greenberg, 2000). It has been reported that functional activities of PMNs were defective in ALL children undergoing chemotherapy (Lejeune et al, 1998). In addition, some morphological alteration in PMN was also observed in CML and MDS cases. In this connection, it may be noted that both CML and MDS are being regarded as a clonal hematopoietic progenitor cell disorder, and therefore it may be interesting to study the status of PMN in these disorders. Furthermore, it has been established that PMN could be activated for the treatment of B-lymphoblastoid malignancies (Valerius et al, 1997), and is more effective against IL-2 transfected tumor cells (Pericle, 1996) and Rituximab directed CD20+ B-cells (Hernandez-Ilizaliturri, 2003). Evidence also suggests that PMN has direct anti-tumor cytotoxic effect (Koga, 2004). Therefore, it would be interesting to find the HLA status (both class I and II) to get an idea about the pathophysiological state of the first line of defense mechanism of the immune system under the condition.

\section{Materials and Methods}

\section{Patients and Normal Individuals}

$10 \mathrm{ml}$ Peripheral blood (PBL) or $2 \mathrm{ml}$ of bone marrow (BM) samples were collected as per institutional ethical guidelines at the time of diagnosis (de novo \& untreated) from the patients suffering from different hematological malignancies. The diagnosis and immunophenotyping categorization of different leukemic patients were done in accordance with the French-AmericanBritish (FAB) as mentioned earlier (Majumder et al, 2005; Majumder et al, 2006). Thus, samples of 15 acute myeloid leukemia (AML) (2 of them are M4 and the rest of the samples are either M1 or M2, immunophenotyping characterization also confirms the light microscopic observation), 14 acute lymphoid leukemia (ALL) (all are L1 or L2; immunophenotyping characterization was either $\mathrm{CD}^{+} 9^{+}$or $\mathrm{CD} 19^{+}$and $\mathrm{CD}^{+} 0^{+} \mathrm{B}$ lineage cell), 16 chronic myeloid leukemia (CML) (all are in chronic phase and are $\mathrm{Ph}^{+}$), 8 chronic lymphoid leukemia (CLL) (all are either CD19+ or both CD19+ and CD20+ CLL) and 8 myelodysplastic syndrome (MDS) (3 are refractory anemia-MDS, 4 are AML-MDS) were used in this study. Peripheral blood was also collected from 15 normal healthy volunteers (NV) following institutional ethical guidelines.

\section{Processing of Samples}

Briefly, collected samples were first diluted about four times and then separated into two compartments by layered preformed Percoll (Sigma, USA) density gradient centrifugation at a density of 1.077 and 1.093 (Pertoft and Lakarent, 1982). Mononuclear cells at 1.077 were removed first, then cells at 1.093 were processed further by using CD15-MACS 
microbeads and MiniMACS column (Miltenyi Biotec $\mathrm{GmbH}$, Germany) for the enrichment of $\mathrm{CD}_{15}{ }^{+}$cells (positive panning procedure). Cells isolated at 1.077 were processed

further to separate leukemic/immature cells as described earlier (Majumder et al, 2005).

\section{Cell Lines}

Raji cell line was obtained from the National Centre for Cell sciences (Pune, India) and was maintained in 5\% CO2 in RPMI 1640 supplemented with $10 \%$ fetal bovine serum (GIBCO-BRL, USA). This has been used as a positive control for flow cytometric analysis of HLA-ABC and HLA-DR (Majumder et al, 2005).

\section{Analysis of Purification of CD15+ Cells by Flow Cytometry}

For the evaluation of the purification of neutrophils, enriched cells (as mentioned in processing of samples) were stained with fluorescent isothiocyanate (FITC) conjugated anti-CD15 (BD 340703), phycoerythrin (PE) conjugated anti-CD8 (BD 340046) and allophycocyanin (APC) conjugated anti-CD34 (BD 340667) and subjected to flow cytometric analysis. Cells are gated (G1) first from FSC vs SSC and then analyzed for CD15 vs SSC, CD15 vs CD34 and CD15 vs CD8 by comparing against the corresponding isotype.

\section{Flow Cytometric Analysis of CD15+ Cell Surface $H L A-A B C$ and $H L A-D R$}

For HLA-ABC and HLA-DR analysis in CD15+ cells' surface, only fresh samples having more than $20 \%$ phenotypic neutrophils in their differential count were used. $100 \mu \mathrm{l}$ of the whole blood was stained with anti-CD15FITC and anti-HLA-ABC-APC (BD 555555) and analyzed for HLA-ABC expression. AntiCD15 was used for flow cytometry based phenotypic selection of neutrophils. Similarly, HLA-DR expression analysis on the $\mathrm{CD}^{2} 5^{+}$cell $100 \mu \mathrm{l}$ of the whole blood was incubated separately with anti-CD15-PE (SC19595PE) together with anti-HLA DR-FITC (BD 347363) and analyzed by flow cytometer (FACSCalibur, Becton Dickinson, USA). For data analysis, neutrophilic gate (G1) was

selected first from FSC and SSC, then from G1 another gate of CD15 vs SSC (G2) was constructed against the corresponding isotype so that only bright cells can be selected (except MDS cases) and the G2 cells were further analyzed for HLA-ABC and HLADR expression. Though there is little chance, however, with this method if leukemic blast cells having aberrant CD15 expression are selected then they may slightly skew the observation.

In each case, data of at least 3000-10000 $\mathrm{CD}^{+} 5^{+}$cells (depending on the case) were analyzed. FITC, PE, and APC conjugated antibody data were analyzed at Fl1, Fl2 and Fl4 respectively in the flow cytometric analysis. All monoclonals, isotypes, fixation buffer, and FACS Lysing solution were purchased from Becton Dickinson (BD), USA. All antibodies were used as per the manufacturer's instruction.

\section{Analysis of HLA-DR Activation on the CD15+ Granulocytes of NV in Presence of Primary Leukemic Cells}

$\mathrm{CD} 15^{+}$granulocytes of $\mathrm{NV}$ were mixed with isolated leukemic cells [having immunophenotyping either $\mathrm{CD}_{3}{ }^{+}$and $\mathrm{CD} 15^{-}$ (for AML) or $\mathrm{CD}^{-} 9^{+}$and $\mathrm{CD}^{-} 5^{-}$(for ALL)] from leukemic patients in $2 \mathrm{ml}$ of RPMI-1640 and were incubated at $37^{\circ} \mathrm{C}$ with the effector to target cells ratio of 10:1 (Effector $=1 \times 10^{6}$ and target $=1 \times 10^{5}$ cells) for 20 minutes time interval (Vella et al, 2002). After incubation, cells are labeled with anti-HLA-DR-FITC and anti-CD15-PE (SC-19595PE) and analyzed by flow cytometry. FITC and PE conjugated antibody, data are analyzed at Fl1 and Fl2 respectively in the FACS analysis. CD15+ cells are gated (G1) first from the CD15 vs FSC compared to the isotype and analyzed for HLA-DR expression both in the control (without any target) and in the test (effector with the target) (Figure 3A). 
Assessment of $C D 15^{+}$Granulocytes' Oxidative Burst Activity Against the Primary Leukemic Cells

To assess the oxidative burst activity (or by ROS production) of the $\mathrm{CD} 15^{+}$granulocytes towards the primary leukemic cells, $5 \times 10^{6}$ $\mathrm{CD}^{1} 5^{+}$cells of $\mathrm{NV}$ were co-cultured with $5 \times 10^{5}$ target cells [HLA downregulated leukemic cells: CML (HLA- $\mathrm{A}^{+}$and $-\mathrm{C}^{+}$, but HLA-B') and/or $\mathrm{CD}^{-} 3^{+}$or $\mathrm{CD} 19^{+}$(both has MFI of HLA-ABC<30)] as well as $\mathrm{K}-562$ and Raji cells] in different tubes (test). The procedure of malignant cells isolation and the assigning of HLA downregulation was described earlier (Majumder et al, 2005). For each set of co-culture reaction, a control tube containing equal number of effector cells and a blank control tube containing equal number of target cells were also taken. To each tube, $200 \mu \mathrm{l}$ of $1 \%$ NBT (nitroblue tetrazolium, SRL, India) solution was added and volume made up to $3 \mathrm{ml}$ with RPMI-1640 and incubated at $37{ }^{\circ} \mathrm{C}$ for 6 hours. After incubation, reaction was stopped by adding chilled $0.1 \mathrm{~N} \mathrm{HCl}$, centrifuged at $1000 \mathrm{~g}$ for 15 minutes, supernatant was discarded and the pelleted blue formazone was extracted with equal volume of pyridine (SRL, India) and absorbance of the solution was taken spectrophotometrically at $488 \mathrm{~nm}$ (Hudson and Hay, 1993; De Toni et al, 1997; Law et al, 2001). In each of the respective cases, blank control was used to set zero in the spectrophotometer, and killing efficacy was evaluated as the differences in absorbance of the test and the control.

\section{Statistical Analysis}

Differences in HLA expression were analyzed by (two-sided) Mann-Whitney $\mathrm{U}$ test. A P value less than or equal to 0.05 was considered significant.

A

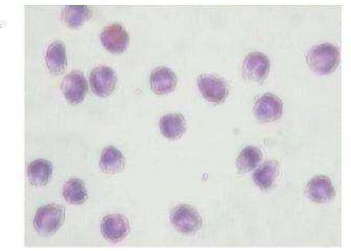

B
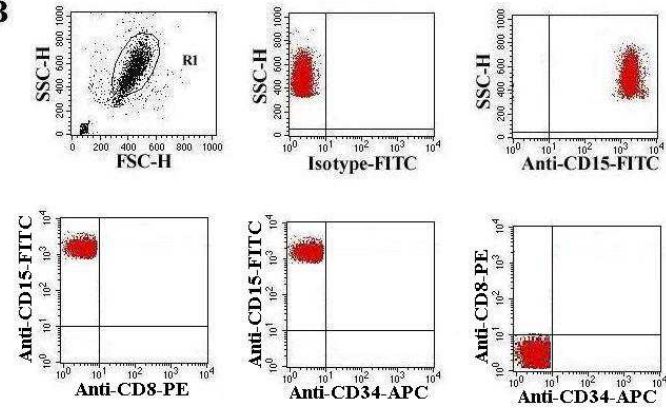

Figure 1: Purification of $\mathrm{CD}^{+}{ }^{+}$granulocytes of hematopoietic origin as the Leishman stained cytocentrifuged slides in (A) and by the flow-cytometric analysis (B). The representation is from NV [Adapted and developed from Majumder D (2012) HLA status on neutrophils and it's implications. In: HLA expression in leukemia, LAP LAMBERT Academic Publishing, pp. 125-150, by permission]. 


\section{Results}

\section{Purification of CD15+ Cells}

The positively panned immuno-magnetically sorted cells were observed to be more than 99\% CD15+ granulocytes (except CML and MDS) as evident by flow-cytometric analysis. Of these cells, 95\% cells were polymorphonuclear neutrophils as evident by the Leishman stained cyto-centrifuged slides (Figure 1). As CML is also being regarded as the clonal stem cell disorder

A
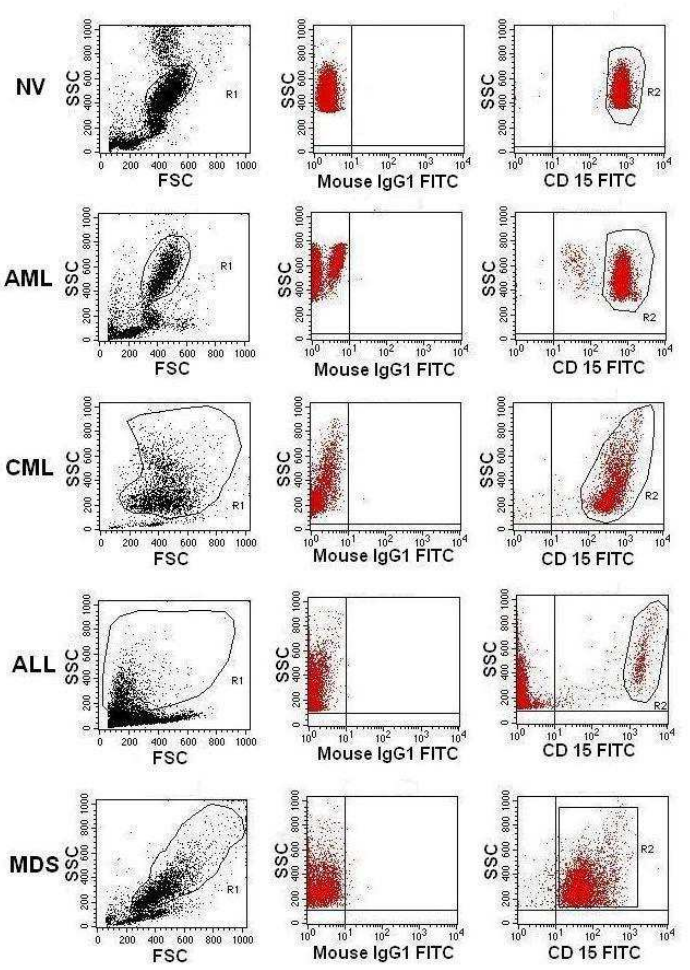

with partial differentiation (Enright and McGlave, 2000) therefore, in several CML cases after density gradient centrifugation followed by positive sorting, enriched cell population though were phenotypically $\mathrm{CD}^{+} 5^{+}(>95 \%)$ but may consist of some immature cells of myeloid lineage (promyelocytes, myelocytes and band cells). This observation was confirmed morphologically (Leishman stained cytospin slides). Moreover, this cell population consisted of $<0.001 \%$ either of $\mathrm{CD}^{2} 4^{+}$or $\mathrm{CD}^{+} \quad$ cell population. B
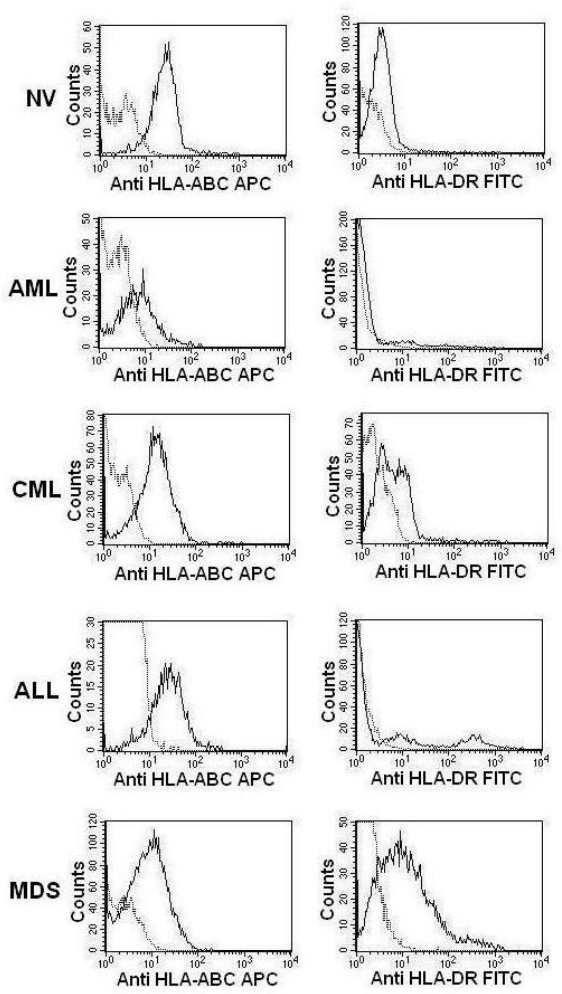

Figure 2: Flow cytometric profiles of $\mathrm{CD}^{+} 5^{+}$cells from a normal volunteer (NV), a patient of acute myeloid leukemia (AML), chronic myeloid leukemia (CML), acute lymphoid leukemia (ALL) and myelodysplastic syndrome (MDS). From the forward (FSC) and side scatter (SSC) plot, cells are gated (G1) and CD15 cells are gated (G2) from SSC and Fl1 (for HLA-ABC)/F12

(for HLA-DR) (A) and analysed for HLA-ABC (in Fl4) and HLA-DR (in Fl1) (B). In the

histogram plot (B), the dotted line represents the isotype control, and the solid line represents the cells stained with anti-HLA-ABC and anti-HLA-DR monoclonal antibody in the respective cases of NV, AML, CML, ALL and MDS [Adapted and developed from Majumder $D$ (2012) HLA status on neutrophils and it's implications. In: HLA expression in leukemia, LAP LAMBERT Academic Publishing, pp. 125-150, by permission]. 
Cell Surface HLA-ABC and HLA-DR Analysis of CD15 ${ }^{+}$Cells

Compared to $\mathrm{CD} 15^{+}$cells of $\mathrm{NV}$, there is a significant decrease in HLA-ABC cell surface expression in $\mathrm{CD}_{15}{ }^{+}$cells of myeloid (AML, CML, MDS) leukemic samples $(\mathrm{P}<0.05)$, whereas there is no significant decrease in lymphoid leukemic samples (Figure 2A). However, in $\mathrm{CD}^{+} 5^{+}$cells of all types of leukemia showed significant increase in HLADR expression compared to that of $\mathrm{CD} 15^{+}$ cells of NV $(\mathrm{P}<0.05)$ (Figure $2 \mathrm{~B})$. The data are depicted in 1.
A

Isotype

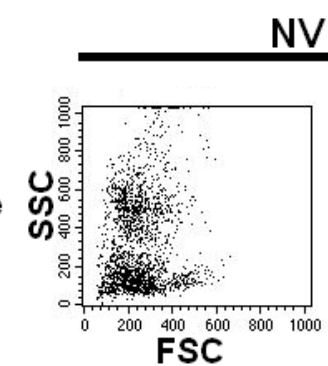

NV vs. AML
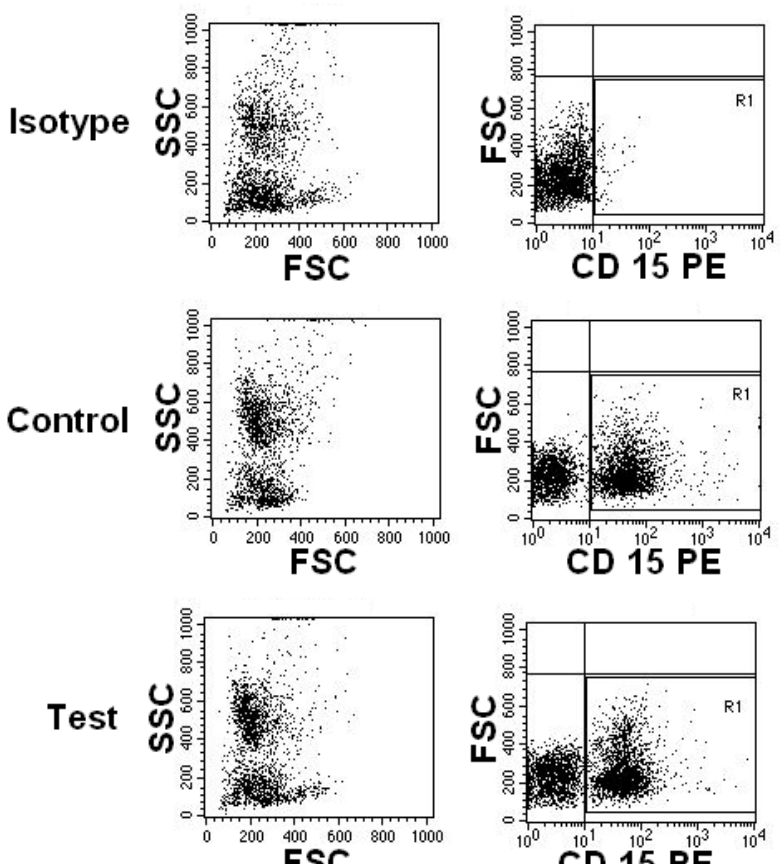

FSC

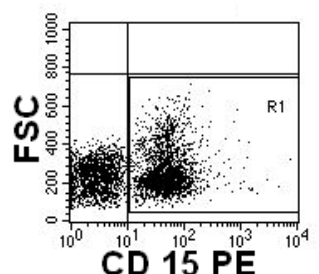

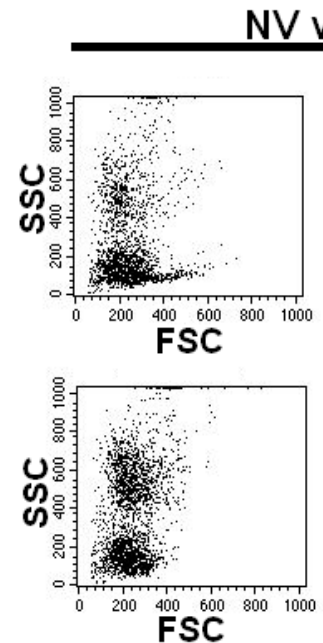

NV vs. ALL
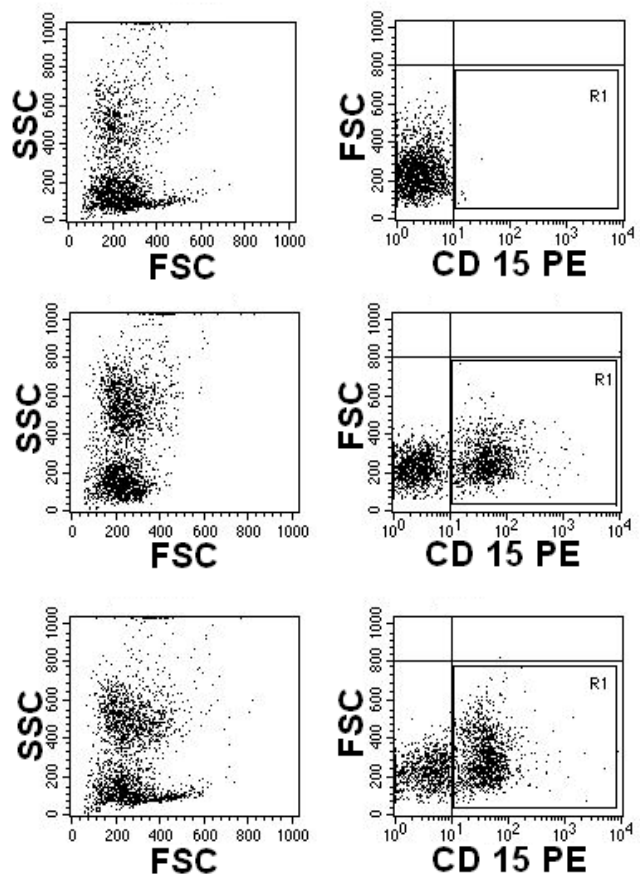
B
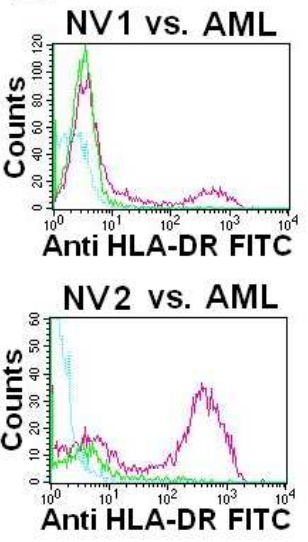
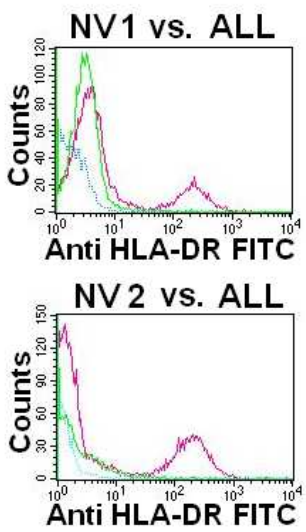
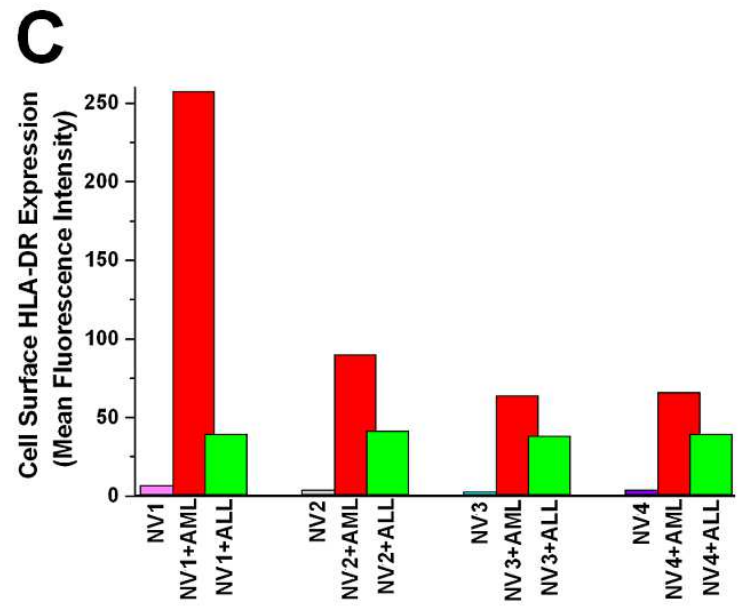

Figure 3. In (A), induced expression of HLA-DR on the CD15+ granulocytes of normal volunteer (NV) in presence of leukemic cells. CD15+ cells are gated (G1) from FSC and CD 15 PE (in FL2) and analyzed for HLA-DR FITC (in FL1). In (B), the sky blue line represents the isotype, the green line represents control (without any leukemic cells) and the red line represents the test (in presence of leukemic cells) expression of HLA-DR by CD15+ cells of NV. Different samples of NV are represented with different numbers. AML and ALL represent acute myeloid leukemic cells, and acute lymphoid leukemic cells, respectively. In (C), HLADR expression analysis of CD15+ cells isolated from different NV (NV1, NV2, NV3 and NV4). Red and green bar represents the HLA-DR expression when CD15+ cells are mixed with AML and ALL cells, respectively. The rest of the bar represents the level of HLA-DR expression by

the $\mathrm{CD}^{+} 5^{+}$cells in control (without the presence of any leukemic cells) [Adapted and developed from Majumder D (2012) HLA status on neutrophils and it's implications. In: HLA expression in leukemia, LAP LAMBERT Academic Publishing, pp. 125-150, by permission].

Table 1. Cell surface HLA-ABC and HLA-DR expression in CD15 ${ }^{+}$cells. Data for mean fluorescence intensity (MFI) are presented as mean \pm SD; Mdn, Max and Min stands for median, maximum and minimum value obtained in the population and $\mathrm{N}$ stands for the number of samples analyzed.

\begin{tabular}{|l|l|l|l|l|l|}
\hline Sample & NV & AML & ALL and CLL & CML $^{*}$ & MDS* $^{*}$ \\
\hline HLA-ABC & $\mathrm{N}=10$ & $\mathrm{~N}=13$ & $\mathrm{~N}=12$ & $\mathrm{~N}=12$ & $\mathrm{~N}=6$ \\
& $21.97 \pm 2.55$ & $10.22 \pm 3.6$ & $24.28 \pm 3.5$ & $16.98 \pm 3.4$ & $9.6 \pm 2.52$ \\
& Mdn 21.97 & Mdn 11.23 & Mdn 24.8 & Mdn 17.68 & Mdn 9.94 \\
& Max 25.35 & Max 17.22 & Max 20.17 & Max 22.35 & Max 12.78 \\
& Min 19.02 & Min 5.9 & Min 18.33 & Min 10.85 & Min 5.22 \\
& & $\mathrm{P}<0.05$ & $\mathrm{NS}$ & $\mathrm{P}<0.05$ & $\mathrm{P}<0.05$ \\
\hline HLA-DR & $\mathrm{N}=10$ & $\mathrm{~N}=13$ & $\mathrm{~N}=12$ & $\mathrm{~N}=12$ & $\mathrm{~N}=6$ \\
& $3.16 \pm 1.4$ & $48.55 \pm 25.42$ & $19.2 \pm 7.3$ & $11.2 \pm 6.14$ & $22.96 \pm 10.78$ \\
& Mdn 3.26 & Mdn 40.12 & Mdn 19.85 & Mdn 11.58 & Mdn 24.85 \\
& Max 0.77 & Max 85.37 & Max 28.24 & Max 25.33 & Max 35.29 \\
& Min 5.16 & Min 15.25 & Min 1.34 & Min 4.21 & Min 3.22 \\
& & $\mathrm{P}<0.01$ & $\mathrm{P}<0.05$ & $\mathrm{P}<0.05$ & $\mathrm{P}<0.01$ \\
\hline
\end{tabular}

NS: Not statistically significant; P means the level of statistical significance; ${ }^{*}$ Data from Majumder D (2012) HLA status on neutrophils and its implications. In: HLA expression in leukemia, LAP LAMBERT Academic Publishing, pp. 125-150, by permission 
Leukemic Cell Induced Activation of HLADR Expression in CD15+ Granulocytes of NV

To analyze whether the primary leukemic cells could induce HLA-DR activation on the $\mathrm{CD}^{+} 5^{+}$granulocytes isolated from NV, CD15+ cells were gated (G1) first from the CD15 vs FSC compared to the isotype. The gated cells were then analyzed for HLA-DR expression both in the control (effector cells without any target) and in the test (effector cells with the target). In the test, there was more expression of HLA-DR compared to the control. Both the primary myeloid and lymphoid leukemic cells could induce HLADR expression in the $\mathrm{CD} 15^{+}$cells of $\mathrm{NV}$ (Figure 3).

Primary leukemic cell Induce ROS production in $\mathrm{CD}_{15^{+}}$Cells of $\mathrm{NV}$

Data show that ROS production in the CD15+ granulocytes isolated from NV by the HLA down-regulated primary leukemic cells. Data also depict that $\mathrm{CD} 15^{+}$granulocytes isolated from different $\mathrm{NV}$ have variation in ROS production as induced by the primary leukemic cells of both myeloid and lymphoid origin (Table 2).

Table 2: The individual data of $\mathrm{CD}^{+} 5^{+}$cells (isolated from different $\mathrm{NV}$ ) phagocytic oxidative burst capacity (or by ROS production) towards primary leukemic cells are expressed as the absorbance of the reduced nitroblue tetrazolium. Raji: Raji cell line, K-562: K-562 cell line,

CML: chronic myeloid leukemia, AML: acute myeloid leukemia, ALL: acute lymphoid leukemia, NV: normal volunteer and the numbers represent different samples.

\begin{tabular}{|l|l|l|l|l|}
\hline $\begin{array}{l}\text { Combination } \\
\text { Set }\end{array}$ & $\begin{array}{l}\text { Effector } \\
\text { (E) sample }\end{array}$ & $\begin{array}{l}\text { Target (T) } \\
\text { sample }\end{array}$ & $\begin{array}{l}\text { E:T cell } \\
\text { Ratio }\end{array}$ & $\begin{array}{l}\text { Absorbance at 488 } \\
\text { nm } \\
\text { (Test - Control) }\end{array}$ \\
\hline 1 & NV2 & K562 & $50: 1$ & 0.022 \\
\cline { 2 - 5 } & NV2 & K562 & $10: 1$ & 0.15 \\
\cline { 2 - 5 } & NV2 & K562 & $1: 1$ & 0.35 \\
\hline 2 & NV3 & K562 & $10: 1$ & 0.04 \\
\cline { 2 - 5 } & NV3 & Raji & $10: 1$ & 0.015 \\
\cline { 2 - 5 } & NV3 & AML5 & $10: 1$ & 0.031 \\
\hline
\end{tabular}

Durjoy Majumder, Subrata Banerjee, Debasis Bandyopadhyay and Sarmila Chandra (2014), Research in Immunology: An International Journal, DOI: 10.5171/2014. 982078 


\begin{tabular}{|l|l|l|l|l|}
\hline \multirow{5}{*}{} & NV3 & ALL5 & $10: 1$ & 0.015 \\
\cline { 2 - 5 } & $\begin{array}{l}\text { Effector } \\
\text { (E) sample }\end{array}$ & $\begin{array}{l}\text { Target (T) } \\
\text { sample }\end{array}$ & $\begin{array}{l}\text { E:T cell } \\
\text { Ratio }\end{array}$ & $\begin{array}{l}\text { Absorbance at 488 } \\
\text { nm } \\
\text { (Test - Control) }\end{array}$ \\
\cline { 2 - 5 } & NV3 & CML9 & $10: 1$ & 0.03 \\
\cline { 2 - 5 } & NV3 & CML12 & $10: 1$ & 0.02 \\
\hline 3 & NV4 & K562 & $10: 1$ & 0.11 \\
\cline { 2 - 5 } & NV4 & Raji & $10: 1$ & 0.2 \\
\cline { 2 - 5 } & NV4 & AML5 & $10: 1$ & 0.07 \\
\cline { 2 - 5 } & NV4 & ALL5 & $10: 1$ & 0.03 \\
\cline { 2 - 5 } & NV4 & CML9 & $10: 1$ & 0.03 \\
\cline { 2 - 5 } & NV4 & CML12 & $10: 1$ & 0.01 \\
\hline 4 & NV5 & K562 & $10: 1$ & 0.05 \\
\cline { 2 - 5 } & NV5 & Raji & $10: 1$ & 0.033 \\
\cline { 2 - 5 } & NV5 & AML8 & $10: 1$ & 0.09 \\
\cline { 2 - 5 } & NV5 & AML9 & $10: 1$ & 0.17 \\
\cline { 2 - 5 } & NV5 & ALL 8 & $10: 1$ & 0.55 \\
\cline { 2 - 5 } & NV5 & ALL9 & $10: 1$ & 0.45 \\
\hline
\end{tabular}

The role of immunological surveillance against tumors was largely focused with the lymphocytes and macrophages. Moreover, it has been suggested previously that $\mathrm{T}$ cell based immunotherapy will not provide any solution to the HLA downregulated cases. Surprisingly, the functionality of neutrophils against primary leukemic cells has not been documented. Recently, several mechanisms about its functionality have been suggested which include antibody dependent cell cytotoxicity (ADCC) (Elasser et al, 1996; Wurflein et al, 1998), Fas ligand mediated apoptosis (Kim et al, 2000), TNF (tumor necrosis factor) related apoptosis inducing ligand (TRAIL) mediated cytotoxicity (Koga et al, 2004), direct cell killing by phagocytosis followed by intracellular $\mathrm{H}_{2} \mathrm{O}_{2}$ and superoxide generation (Lichtenstein and Kahle, 1985). We found that $\mathrm{CD}_{15}{ }^{+}$cells isolated from $\mathrm{NV}$ have a direct killing capacity of HLA downregulated primary leukemic cells, and also have the ability to express HLA class II in presence of primary leukemic cells. In this study, the enhanced HLA-DR expression by $\mathrm{CD}^{2} 5^{+}$cells of leukemic patients may be due to the constant cell contact with the malignant cells within the hematopoietic system. This work and our previous work confirm these observations (Majumder, 2012).

It is well established that leukemic patients of all types are more prone to the secondary infection (Estey et al, 2000; Dubansky et al, 1989; Benz et al, 2000; Crammer et al, 1977; Greenberg, 2000). Therefore, CD15+ cells transplantation to leukemic patients (either allogenic or autologous, depending on the case) may have a beneficial role, not only in preventing the secondary infection, but also in killing HLA downregulated primary leukemic cells by ROS production (Hudson and Hay, 1993). It may also be noted that recent clinical trials involving cord blood transplantation in hematological malignancies indicated a better outcome with cells containing a higher neutrophilic 
counts (Ishikawa and Miyazaki, 2005). Moreover, due to its capacity to express HLA$\mathrm{DR}$, a long-term benefit of $\mathrm{T}$ cell priming by PMNs would be able to provide an added advantage. Thus, as suggested previously (Arcese et al, 2006), the therapeutic application of $\mathrm{CD}^{+} 5^{+}$cells may bridge the innate and adaptive immunity in the state of hematological malignancies. Finally, our previous work and that of others (Polakova et al, 2003; Majumder et al, 2006) suggest that innate immune mechanism may be harped in to produce a positive supportive treatment for leukemia.

\section{Acknowledgement}

We are grateful to the clinicians and pathologists working in the Ramakrishna Mission Seva Prathisthan, Kothari Medical Center, Kolkata for collecting samples and clinical data. DM acknowledges University Grants Commission, INDIA for providing SRF (NET) Fellowship.

\section{References}

1. Arcese W, Rocha V, Labopin M, Sanz G, Lori AP, de Lima M, Sirvent A, Busca A, Asano S, Ionescu I, Wemet P, Glucman E (2006) "Unrelated cord blood transplants in adults with hematologic malignancies," Haematologica 91:223-230.

2. Benz SL, Steuber P, Poplack DG (2000) Clinical manifestations of acute lymphoblastic leukemia. In: Hoffman R, Benz Jr. EJ,. Shantil SJ, Furie B, Cohen HJ, Silberstein LE, McGlave P (Eds.), Hematology: Basic principles and practice, $3^{\text {rd }}$ ed., Churchill Livingstone, New York, London, Philadelphia. pp. 1070-1078.

3. Cramer E, Auclair C, Hakim J, Feliu E, Boucherot J, Troube H, Bernard JF, Bergogne E, Boivin P (1977) "Metabolic activity of phagocytosing granulocytes in chronic granulocytic leukemia: ultrastructural observation of a degranulation defect," Blood 50:93-106.
4. De Toni S, Piva E, Lapolla A (1997) "Respiratory burst of neutrophils in diabetic patients with periodontal disease," Annals of New York Academy of Sciences 832:363-367.

5. Dubansky AS, Boyett JM, Falletta J, Mahoney DH, Land VJ, Pullen J, Buchanan G (1989) "Isolated thrombocytopenia in children with acute lymphoblastic leukemia: a rare event in a Pediatric Oncology Group Study," Pediatrics 84:1068-1071.

6. Elasser D, Valerius T, Repp R, Weiner GJ, Deo Y, Kalden JR, van de Winkel JG, Stevenson GT, Glennie MJ, Gramatzki M (1996) "HLA class II as potential target antigen on malignant B cells for therapy with bispecific antibodies in combination with granulocyte colony-stimulating factor," Blood 87:3803-3812.

7. Enright H, McGlave P (2000) Chronic myelogenous leukemia. In: Hoffman R, Benz Jr. EJ, Shantil SJ, Furie B, Cohen HJ, Silberstein LE, McGlave P (Eds.) Hematology: Basic principles and practice, $3^{\text {rd }}$ ed., Churchill Livingstone, New York, London, Philadelphia. pp $1155-1171$.

8. Estey EH, Kantarjian H, Keating MJ (2000) Therapy for acute myeloid leukemia. In: Hoffman R, Benz Jr. EJ,. Shantil SJ, Furie B, Cohen HJ, Silberstein LE, McGlave P (Eds.), Hematology: Basic principles and practice, $3^{\text {rd }}$ ed., Churchill Livingstone, New York, London, Philadelphia. pp. 1025-1042.

9. Ferron A, Perez-Ayala $M$, Concha A, Cabrera T, Redondo M, Oliva MR, RuizCabello F, Garrido F (1989) "MHC class I and II antigens on gastric carcinomas and autologous mucosa," Journal of Immunogenetics 16:413-423.

10. Gerrard TL, Cohen DJ, Kaplan AM (1981) "Human neutrophil-mediated cytotoxicity to tumor cells," Journal of National Cancer Institute 66:483-488.

11. Greenberg PL (2000) Myelodysplastic Syndrome. In: Hoffman R, Benz Jr. EJ, Shantil 
SJ, Furie B, Cohen HJ, Silberstein LE, McGlave $P$ (Eds.) Hematology: Basic principles and practice, $3^{\text {rd }}$ ed., Churchill Livingstone, New York, London, Philadelphia. pp 1106 -1129.

12. Hernandez-Ilizaliturri FJ, Jupudy V, Ostberg J, Oflazoglu E, Huberman A, Repasky E, Czuczman MS (2003) "Neutrophils contribute to the biological antitumor activity of rituximab in a non-Hodgkin's lymphoma severe combined immunodeficiency mouse model," Clinical Cancer Research 9:5866-5873.

13. Hoelzer D (2000) Acute lymphocytic leukemia in adults. In: Hoffman R, Benz Jr. EJ,. Shantil SJ, Furie B, Cohen HJ, Silberstein LE, McGlave $P$ (Eds.), Hematology: Basic principles and practice, $3^{\text {rd }}$ ed., Churchill Livingstone, New York, London, Philadelphia. pp. 1089-1105.

14. Hudson L, Hay FC (1993) Neutrohil respiratory burst activity. In: Practical Immunology, Blackwell Scientific, Oxford, London, Victoria. pp. 38-42.

15. Ishikawa F, Miyazaki S (2005) "New biodefense strategies by neutrophils," Archivum Immunologiae et TherapiaeExperimentalis 53:226-233.

16. Katano M, Torisu M (1982) "Neutrophilmediated tumor cell destruction in cancer ascites," Cancer 50:62-68.

17. Kim JM, Kim JS, Jung HC, Song IS, Kim CY (2000) "Apoptosis of human gastric epithelial cells via caspase- 3 activation in response to Helicobacter pylori infection: possible involvement of neutrophils through tumor necrosis factor alpha and soluble Fas ligands," Scandanavium Journal of Gastroenterology 35:40-48.

18. Koga Y, Matsuzaki A, Suminoe A, Hattori H, Hara T (2004) "Neutrophil-derived TNFrelated apoptosis-inducing ligand (TRAIL): a novel mechanism of antitumor effect by neutrophils," Cancer Research 64:1037-1043.
19. Law S, Maiti D, Palit A, Majumder D, Basu K, Chaudhuri S, Chaudhuri S (2001) "Facilitation of functional compartmentalization of bone marrow cells in leukemic mice by biological response modifiers: an immunotherapeutic approach," Immunology Letters 76:145-152.

20. Lejeune M, Ferster A, Cantinieaux B, Sariban E (1998) "Prolonged but reversible neutrophil dysfunctions differentially sensitive to granulocyte colony-stimulating factor in children with acute lymphoblastic leukaemia," British Journal of Haematology 102:1284-1291.

21. Lichtenstein A, Kahle J (1985) "Antitumor effect of inflammatory neutrophils: characteristics of in vivo generation and in vitro tumor cell lysis," International Journal of Cancer 35:121-127.

22. Majumder D (2012) HLA status on neutrophils and it's implications. In: HLA expression in leukemia, LAP LAMBERT Academic Publishing, Saarbrucken, pp. 125150.

23. Majumder D, Bandyopadhyay D, Chandra S, Mukherjee N, Banerjee S (2006) "Lack of HLA-E surface expression is due to deficiency of HLA-E transcripts in the malignant hematopoietic cells of leukemic patients," Leukemia Research 30:242-5.

24. Majumder D, Bandyopadhyay D, Chandra S, Mukhopadhayay A, Mukherjee N, Bandyopadhyay SK, Banerjee S (2005) "Analysis of HLA class Ia transcripts in human leukaemias," Immunogenetics 57:579589.

25. Pericle F, Kirken RA, Epling-Burnette PK, Blanchard DK, Djeu JY (1996) "Direct killing of interleukin-2-transfected tumor cells by human neutrophils," International Journal of Cancer 66:367-373.

26. Pertoft H, Lakarent P (1982) Sedimentation of cells in colloidal silica 
(Percoll). In: Pretlow TG, Tretlow TP (Eds.) Cell separation - Methods and selected

application, Vol. I. Academic Press, USA. pp 115-152.

27. Pickaver AH, Ratcliffe NA, Williams AE (1972) "Cytotoxic effects of peritoneal neutrophils on a syngenic rat tumour," Nature New Biology 235:186-187.

28. Polakova K, Krcova M, Kuba D, Russ G (2003) "Analysis of HLA-G expression in malignant hematopoetic cells from leukemia patients," Leukemia Research 27:643-648.

29. Pure E (2000) Overview of the immune system (Including compartmentalization of the immune response), In: Hoffman R, Benz Jr. EJ, Shantil SJ, Furie B, Cohen HJ, Silberstein LE, McGlave P (Eds.) Hematology: Basic principles and practice, $3^{\text {rd }}$ ed. Churchill Livingstone, New York, London, Philadelphia, pp. 74-79.
30. Valerius T, Elsasser D, Repp R, Van de Winkel JG, Gramatzki M, Glennie M (1997) "HLA class II antibodies recruit G-CSF activated neutrophils for treatment of B cell malignancies," Leukemia Lymphoma 26:261269.

31. Vella A, Sartoris S, Bambara L (2002) "Cell contact-dependent PMN HLA-DR and CD69 membrane expression induced by autologous mono-lymphocytes and cell lines," Inflammation 26:143-152.

32. Wurflein D, Dechant M, Stockmeyer B, Tutt AL, Hu P, Repp R, Kalden JR, van de Winkel JG, Epstein AL, Valerius T, Glennie M, Gramatzki M (1998) "Evaluating antibodies for their capacity to induce cell-mediated lysis of malignant B cells," Cancer Research 58:3051-3058.

33. Zivokovic M, Poljak-Blazi M, Egger G, Sunjic SB, Schaur RJ, Zarkovic N (2005) "Oxidative burst and anticancer activities of rat neutrophils," Biofactors 24:305-312. 